\title{
Gejala Buli Secara Fizikal yang Semakin Berleluasa di Sekolah
}

\author{
Ngo Yew Yung ${ }^{1}$, Nasharuddin Imraan Bin Rosli ${ }^{1}$, Muhammad Afiq Aizaq Bin Mat Salleh \\ (a) Sukri ${ }^{1}$, Nasharuddin Imraan Bin Rosli ${ }^{1}$, Fatin Nur Syahirah Binti Abdul Hamid ${ }^{1}$, Nor \\ Nasihah Binti Mohd Robi ${ }^{1}$, Nurul Nasuha Binti Rosly ${ }^{1}$, Mohd Razimi Bin Husin ${ }^{1}$
}

${ }^{1}$ Faculty of Human Development, Universiti Pendidikan Sultan Idris, Malaysia.

Article History
Received:
13.03.2019
Revised:
25.04.2019
Accepted:
23.06.2019
*Corresponding Author:
Mohd Razimi Husin
Email:
razimi@fpm.upsi.edu.my

Article History

Received:

Revised:

Accepted:

23.06.2019

Mohd Razimi Husin

razimi@fpm.upsi.edu.my
Abstrak: Konsep buli boleh dilihat kepada elemen-elemen yang terdapat di dalam tingkahlaku buli seperti pembuli, mangsa buli, tujuan dan kesan tingkahlaku buli. Lumrahnya pembuli adalah mereka yang mempunyai sifat sebagai orang lebih kuat, berkuasa dan lebih bermampuan untuk melakukan tingkah laku buli. Kekuatan ini biasanya boleh diperlihatkan sama ada ia adalah secara berseorangan atau berkumpulan. Mereka yang menjadi mangsa kepada pembuli adalah mereka yang lebih lemah dan tidak bermampuan untuk menandingi kekuatan dan kekuasaan si pembuli. Kelemahan ini termasuk lemah dari aspek fizikal dan lain-lain.Oleh kerana itu, maka dilakukan kajian mengenai gejala buli secara fizikal yang semakin berleluasa di sekolah. Metodologi kajian ini iaitu reka bentuk kajian gejala buli secara fizikal yang semakin berleluasa di sekolah adalah berbentuk deskriptif dengan menggunakan keadah temu bual. Antara temu bual yang telah pengkaji buat adalah temu bual semi struktur. Format semi struktur terletak di antara temu bual berstruktur dan tidak berstruktur. Secara keseluruhan dapatlah dirumuskan bahawa perlakuan buli di sekolah menengah adalah sesuatu yang perlu diambil perhatian serius seperti mana di sekolah-sekolah dalam bandar dan luar bandar yang lain.

Kata Kunci: Buli Fizikal, Masalah Sekolah, Pelajar.

Symptoms of Physical Bullying Increasingly at School

Abstract: The concept of bullying can be seen in the elements of bullying behaviors such as bullying, victim bullying, the purpose and impact of bullying behavior. Generally bullies are those who have a stronger personality, are more powerful and capable of committing bullying behavior. This power can usually be seen either individually or in groups. The victims of the bullying are the weaker ones and unable to match the power and authority of the bully. These weaknesses include physical and other weaknesses. Therefore, a study on physical symptoms of bullying has become widespread in schools. The methodology of this study, which is the design of the study of physical bullying symptoms prevalent in schools, is descriptive using interview methods. Among the interviews that have been researched are semi-structured interviews. The semi-structured format is located between structured and unstructured interviews. It can be concluded that bullying in secondary schools is something that should be taken seriously as it is in other urban and rural schools.

Keyword: Physical Bullying, School Issues, Students. 
Ngo Yew Yung, Nasharuddin Imraan Bin Rosli, Muhammad Afiq Aizaq Bin Mat Salleh @, Sukri, Nasharuddin Imraan Bin Rosli1, Fatin Nur Syahirah Binti Abdul Hamid, Nor Nasihah Binti Mohd Robi, Nurul Nasuha Binti Rosly, Mohd Razimi Bin Husin.

Gejala Buli Secara Fizikal yang Semakin Berleluasa di Sekolah.

International Journal of Humanities, Management, and Social Science, vol. 2, no. 1, pp. 65-75, June 2019. DOI: 10.36079/lamintang.ij-humass-0201.24

\section{Pendahuluan}

Terdapat banyak tafsiran dan definisi menjelaskan tentang tingkahlaku buli. Tafsiran salahlaku buli ditafsir dari pelbagai sudut. Semakin banyak sudut yang digunakan untuk mentafsir buli, tafsiran tentang buli akan menjadi lebih luas dan mendalam. Terdapat juga kajian-kajian yang telah dilakukan tentang tingkahlaku buli oleh para pengkaji. Dapatan daripada kajian-kajian ini telah memberi ruang yang secukupnya untuk mendefinisikan istilah buli hasil daripada kajian mereka. Secara umumnya, tingkah laku buli ditafsirkan sebagai tingkahlaku yang dilakukan oleh seseorang dengan mengasari orang lain. Lumrahnya orang yang dikasari adalah bersifat lebih lemah dibandingkan dengan mereka yang mengasarinya. Tujuan tinglakh laku buli ini dilakukan adalah untuk menunjukkan si pembuli lebih berkuasa dan menjadikan mangsa mudarat sama ada dari aspek fizikal ataupun psikologikal.

Buli adalah salah laku yang dilakukan secara sedar sama ada berbentuk fizikal atau psikologikal ke atas mangsa yang lebih lemah bertujuan mendatangkan kemudaratan fizikal atau psikologi. Perlakuan ini dilakukan secara berulang sehingga pembuli merasa seronok dan puas. Sementara, Yaakub [1], pula mendefinisikan buli sebagai tingkah laku agresif sama ada fizikal atau psikologikal yang dilakukan secara berulang kali ke atas mangsa dan ia bertujuan mendatangkan perasaan tidak seronok.

Difahamkan konsep buli boleh dilihat kepada elemen-elemen yang terdapat di dalam tingkahlaku buli seperti pembuli, mangsa buli, tujuan dan kesan tingkahlaku buli [2]. Pembuli ialah mereka yang melakukan tingkah laku buli kepada managsa buli. Lumrahnya pembuli adalah mereka yang mempunyai sifat sebagai orang lebih kuat, berkuasa dan lebih bermampuan untuk melakukan tingkah laku buli. Kekuatan ini biasanya boleh diperlihatkan sama ada ia adalah secara berseorangan atau berkumpulan. Mereka yang menjadi mangsa kepada pembuli adalah mereka yang lebih lemah dan tidak bermampuan untuk menandingi kekuatan dan kekuasaan si pembuli. Kelemahan ini termasuk lemah dari aspek fizikal dan lain-lain. Sebagai contoh lemah dari aspek fizikal, mangsa buli tidak berupaya untuk melawan pembuli. Mangsa buli juga takut dan tidak berupaya untuk mengadu kepada kawan-kawan, guru atau ibu bapa mereka. Biasanya mangsa buli adalah terdiri daripada mereka secara berseorangan.

Tujuan membuli adalah pembuli ini menunjukkan bahawa mereka adalah lebih kuat atau berkuasa dibandingkan dengan mangsa. Pembuli juga merasa puas apabila melakukan buli terhadap orang lain. Semakin mangsa rasa takut semakin tinggi darjah kepuasan yang dirasai oleh pembuli. Selain daripada itu, tujuan tingkah laku buli adalah untuk menjadikan mereka yang lemah menjadi akur dan menghormati si pembuli. Untuk menjadikan situasi berlaku seperti yang diharapkan oleh pembuli, pembuli akan mencederakan mangsa sama ada secara fizikal atau psikologi. Kesan yang akan dirasai oleh mangsa ialah kecederaan, ketakutan dan rasa tidak selesa serta tenteram

Kesan bagi pembuli ialah pembuli akan merasa lebih kuat dan berkuasa serta merasa puas apabila melihat mangsa buli rasa takut dan akur dengan kekuatan dan kuasa yang ada pada pembuli. Pembuli juga akan merasa puas melihat mangsa berada dalam keadaan yang tidak selesa dan tenteram. Sesetengah kes, pembuli akan merasa puas sekirannya mangsa menjadi cedera parah dan bermungkinan mangsa akan meninggal dunia. Manakala untuk mangsa buli pula, mangsa buli akan merasa tertekan, takut, gelisah dan tidak tenteram sepanjang masa. Terdapat juga mangsa menjadi cedera dan cacat. Kesan ini akan meninggalkan kesan sepanjang hidup mangsa dan sesetengah kes buli boleh mengakibatkan kematian.

Disebabkan pembuli dan mangsa buli tidak menyedari bahawa kelebihan dan kelemahan masingmasing boleh menjadi penambah baik sesama mereka sendiri, maka kelebihan dan kelemahan itu telah menjadi antara faktor pendorong kepada mereka terbabit sebagai pembuli dan mangsa buli.

Seterusnya, Menurut Mahadi [3] tingkah laku buli yang berpunca dari pelbagai faktor seperti faktor biologi dan perangai, pengaruh keluarga, rakan sebaya dan persekitaran telah menyebabkan masalah ini terus berleluasa dalam kalangan para pelajar, khususnya pelajar sekolah menengah. Pada peringkat usia ini, mereka sedang mengalami krisis identiti iaitu mencari identiti tersendiri untuk berhadapan dengan keluarga, rakan sebaya dan masyarakat sekeliling. Justeru itu, pelajar masih mentah dalam kehidupan ini sering terpengaruh dengan persekitaran yang akan memesongkan mereka dari landasan yang sebenar, seterusnya terlibat dengan gejala tingkah laku buli ini.

Wujud kesan-kesan negatif akibat bertingkah laku buli terutamanya terhadap pembuli seperti suka melanggar peraturan sekolah, bersikap lebih angkuh dan pelbagai lagi kesan-kesan negatif yang akan merosakkan diri pembuli. Manakala kesan negatif terhadap mangsa buli pula adalah seperti takut hendak ke sekolah, suka menyendiri dan sebagainya. Kesan-kesan negatif ini juga akan menyebabkan 
Ngo Yew Yung, Nasharuddin Imraan Bin Rosli, Muhammad Afiq Aizaq Bin Mat Salleh @, Sukri, Nasharuddin Imraan Bin Rosli1, Fatin Nur Syahirah Binti Abdul Hamid, Nor Nasihah Binti Mohd Robi, Nurul Nasuha Binti Rosly, Mohd Razimi Bin Husin.

Gejala Buli Secara Fizikal yang Semakin Berleluasa di Sekolah.

International Journal of Humanities, Management, and Social Science, vol. 2, no. 1, pp. 65-75, June 2019. DOI: 10.36079/lamintang.ij-humass-0201.24

proses pengajaran dan pembelajaran remaja terbabit akan terbantut, dan seterusnya bakal merosakkan masa depan mereka sendiri.

Objektif kajian temu bual yang pengkaji jalankan terhadap empat orang guru di sekolah-sekolah yang berlainan, iaitu Sekolah Menengah Sains Tapah, Sekolah Menengah Kebangsaan Changkat Lada, Sekolah Menengah Kebangsaan Tinggi Batu Pahat dan Sekolah Menengah Kebangsaan Seri Ampang, Ipoh. Objektif kajian ini juga dijalankan adalah untuk mengumpul dan mengkaji respon guru-guru berkenaan isu buli di sekolah, sama ada positif atau sebaliknya melalui kaedah temubual yang dijalankan.

Selain itu, tujuan kajian juga adalah untuk mengenalpasti isu-isu permasalahan buli yang sering berlaku dalam kalangan pelajar terutama pelajar-pelajar yang tinggal di asrama. Seterusnya, objektif kajian temu bual ini adalah untuk menilai serta mengkaji proses pengawalan, pemantauan, pelan tindakan serta strategi yang digunakan oleh guru-guru bagi mencegah isu-isu gejala buli di sekolah. Kajian temu bual ini juga membolehkan pengkaji untuk menerima pendapat dan cadangan serta penambahbaikan yang boleh pengkaji aplikasikan di sekolah pada masa akan datang, serta melatih diri pengkaji meningkatkan skill komunikasi secara formal bersama pihak-pihak sekolah mahupun pihak atasan.

Di samping itu, matlamat pengkaji dalam proses kaji selidik secara temu bual ini dijalankan adalah untuk menambah ilmu pengetahuan pengkaji tentang persediaan menangani kejadian-kejadian buli yang seringkali berlaku dimana-mana sekolah. Selain itu, matlamat dan tujuan kajian pengkaji juga untuk menimba ilmu pengetahuan tentang cara-cara berurusan dengan pihak sekolah dan sebagainya. Ia secara tidak langsung melatih pengkaji untuk bersifat sabar dalam menghadapi dunia perguruan dan menyuntik minat dan semangat yang mendalam serta rasa tanggungjawab yang tinggi untuk mendidik para pelajar tentang kesedaran menangani isu buli ini di sekolah kelak.

\section{Sorotan Kajian}

Sorotan kajian merupakan penyataan atau fakta yang menyokong sesuatu objektif. Ia membuktikan bahawa teori yang digunakan bukanlah hanya rekaan. Di dalam sorotan kajian ini mengandungi penyataan, kaedah, teori, pendapat, penilaian dan laporan kajian berkenaan tajuk yang dipilih penyelidik. Sumber-sumber kajian boleh diambil daripada artikel, jurnal, tesis atau kenyataan daripada seseorang pakar.

\subsection{Tingkah Laku Buli dalam Kalangan Pelajar di Sekolah.}

Kajian Khalid [3] mengenai "Tingkah Laku Buli dalam Kalangan Pelajar Sekolah Menengah Kebangsaan Agama di Sarawak" menyebutkan bahawa ciri-ciri tingkah laku buli dari jenis fizikal merupakan ciri-ciri tingkah laku buli yang paling dominan dilakukan oleh pembuli dan mangsa buli. Hasil kajian Khalid [3] juga mendapati bahawa punca tingkah laku buli fizikal yang sering dilakukan dalam kalangan pelajar yang menjadi pembuli adalah untuk menunjukkan dirinya kuat, manakala dalam kalangan pelajar yang menjadi mangsa buli adalah seperti umurnya yang lebih muda. Kesan fizikal yang wujud dalam kalangan pembuli adalah seperti suka melanggar peraturan sekolah manakala dalam kalangan mangsa buli pula adalah seperti suka ponteng sekolah atau kelas. Beberapa cadangan seperti kerjasama pihak luar seperti Polis, Pihak Berkuasa Tempatan dan penglibatan masyarakat adalah perlu untuk mencegah dan menghentikan tingkah laku buli dari terus berleluasa.

Teori yang boleh dikaitkan adalah teori Sigmund Freud. Menurut Freud [4], berpendapat bahawa terdapat tiga komponen personaliti iaitu id, ego dan superego yang sering mempengaruhi antara satu sama lain dalam mengawal perlakuan manusia. Id merupakan personaliti primitif (individu yang belum mengenali dunia luar) dan paling sukar untuk dicapai. Tindakan id sentiasa bertindak berdasarkan prinsip keseronokan (keseimbangan atau homestatik). Malahan sifat id juga sering mangambil tindakan yang luar kawal dengan melakukan sesuatu perkara yang tidak logik dan tidak bermoral untuk memuaskan nafsu naluri semata-mata. Sebagai contoh, seorang pelajar telah melakukan kesalahan dengan membuli secara fizikal terhadap rakan kelasnya kerana sifat idnya yang tidak berpuas hati dan menyimpan dendam untuk membalas sesuatu dengan kejahatan supaya ia dapat memenuhi kepuasannya.

Ego pula membawa maksud sifat ego yang mengawal tindakan-tindakan yang hendak dilakukan oleh seseorang, memilih persekitaran yang sesuai serta menentukan naluri mana atau cara yang akan dipuaskan. Ego ini berpandukan prinsip realiti (segala tindakan dipertimbangkan). Ia juga merupakan sebagai orang tengah di antara desakan-desakan id, penentuan-penentuan superego dan keadaan 
Ngo Yew Yung, Nasharuddin Imraan Bin Rosli, Muhammad Afiq Aizaq Bin Mat Salleh @, Sukri, Nasharuddin Imraan Bin Rosli1, Fatin Nur Syahirah Binti Abdul Hamid, Nor Nasihah Binti Mohd Robi, Nurul Nasuha Binti Rosly, Mohd Razimi Bin Husin.

Gejala Buli Secara Fizikal yang Semakin Berleluasa di Sekolah.

International Journal of Humanities, Management, and Social Science, vol. 2, no. 1, pp. 65-75, June 2019. DOI: 10.36079/lamintang.ij-humass-0201.24

persekitaran. Sifat ego ini adalah seseorang yang sentiasa berfikiran waras, logik dan rasional. Selain itu, ia juga bertindak melalui proses sekunder di mana pemikiran yang logik dan rasional bagi merancang sesuatu tindakan untuk mengurangkan sebarang ketegangan. Ia juga memiliki kuasa atau kawalan ke atas fungsi kognitif atau intelektual. Contohnya, seorang pelajar asrama telah menahan perasaan yang marah dan dendam terhadap rakan yang lain kerana telah membulinya. Namun ego telah menahan dan mengawal sifat idnya untuk membalas dendam. Hal ini kerana, dia sentiasa berfikiran rasional dalam menangani masalahnya dan tidak mahu mengeruhkan lagi keadaan.

Komponen terakhir adalah superego yang memberi definisi sebagai penentu apakah tingkahlaku itu baik atau buruk. Superego ini mempunyai sifat idealistik dan perfectionist. Fungsi superego adalah untuk menyekat ego dari menuruti id dan mendorong ego untuk menerima nilai-nilai dan matlamatmatlamat moral. Memujuk ego untuk menggantikan matlamat realistik dengan matlamat moral dan berusaha ke arah mencapai kesempurnaan. Tamsilnya, seorang pelajar lelaki telah dibuli secara mental oleh rakan kelasnya kerana dia seorang anak yatim piatu. Oleh itu, dia telah merancang untuk memukul rakannya untuk melepaskan sifat idnya yang tinggi namun begitu, dia memikirkan tindakannnya adakah ia memberi satu keburukan atau kebaikan kepadanya.

Kesimpulannya, dalam perhubungan antara id, ego dan superego ialah id sebagai pendesak, ego sebagai pengatur dan superego adalah sebagai pemerhati serta mengurus id dan ego.

\subsection{Buli di Kalangan Pelajar Sekolah Menengah Luar Bandar}

Kajian Hassan et. Al [5] mengenai "Buli di Kalangan Sekolah Rendah Luar Bandar: Kajian Kes di Kawasan Felda Utara Kedah- Perlis, Malaysia" menjelaskan bahawa tingkah laku buli dalam kalangan pelajar sekolah pada tahun 2016. Hassan et al. [5] mengatakan kajian ini dilihat secara khusus kejadian dan tingkah laku buli dalam komuniti setempat yang hanya tertumpu pada lokasi kelompok masyarakat yang berciri likat iaitu komuniti dalam perladangan Felda. Kawasan pendudukan masyarakat setempat yang terletak jauh di dalam kawasan perladangan Felda membuatkan ciri-ciri budaya masyarakat setempat tersebut hanya berada atau terserap dalam kalangan komuniti itu sahaja. Pergaulan sosialisasi juga adalah terhad pada kelompok komuniti tersebut berbanding dengan sosialisasi masyarakat kelompok yang berada luar daripada kawasan perladangan Felda. Dalam kelompok masyarakat Felda, konsep 'tiada sesiapa yang tidak tahu sesiapa' dan setiap apa yang berlaku akan diketahui oleh setiap keluarga di Felda menjadikan kelikatan masyarakat Felda yang tiada pada masyarakat lain walaupun pada masyarakat komuniti jenis perkampungan di sesebuah kawasan lain.

Oleh yang demikian, pengkaji tertarik dengan persoalan; adakah dengan kelikatan sosialisasi dan perkongsian satu budaya komuniti masyarakat setempat di kawasan pendudukan perladangan membuatkan kurangnya tingkah laku langsang (buli) terutama di kalangan remaja sekolah menengah di kawasan perladangan Felda.

Teori yang boleh dikaitakan dengan kajian pengkaji tersebut ialah Teori Hierarki Maslow. Teori Abraham Maslow dikenali sebagai teori hierarki keinginan. Maslow [6] mempamerkan lima keperluan tingkah laku yng mempengaruhi dan mengarah tingkah laku manusia. Susunan keperluan tersebut adalah kesempurnaan kendiri, keperluan penghargaan kendiri, keperluan kasih sayang, keperluan keselamatan, dan keperluan fisiologi (asas). Perkara yang boleh dikaitkan dengan kajian yang telah pengkaji lakukan ialah kasih sayang. Hal ini demikian kerana, dalam memenuhi keperluan kasih sayang pula, manusia perlukan hubungan dengan insan lain. Kita semua pada asasnya iailah haiwan yang bersosial, iaitu kita perlukan kasih saying daripada orang lain.

Oleh itu, manusia ini sememangnya tidak boleh wujud sendirian. Oleh itu, keperluan kasih sayang ini juga perlu ada pada setiap kanak-kanak supaya tidak berlakunya percanggahan dalam diri mereka. Justeru itu, kebanyakkan kes buli secara fizikal ini terjadi disebabkan perlajar yang membuli kurang kasih sayang daripada ibu bapa. Pelajar yang membuli akan melepaskan perasaan marah dan ketidakpuashatian mereka terhadap mangsa buli. Ini akan memenuhi kepuasan mereka setelah melakukan kegiatan buli secara fizikal tersebut.

\subsection{Persepsi Guru dan Pelajar terhadap Perlakuan Buli di Kalangan Pelajar Sekolah Menengah Daerah Batu Pahat}

Apabila pengkaji membuat penyelidikan mengenai Persepsi guru dan pelajar terhadap perlakuan buli di kalangan pelajar sekolah menengah, telah mendapati bahawa terdapat satu kajian mengaji kajian yg pengkaji kaji pada tahun 2015. 
Ngo Yew Yung, Nasharuddin Imraan Bin Rosli, Muhammad Afiq Aizaq Bin Mat Salleh @, Sukri, Nasharuddin Imraan Bin Rosli1, Fatin Nur Syahirah Binti Abdul Hamid, Nor Nasihah Binti Mohd Robi, Nurul Nasuha Binti Rosly, Mohd Razimi Bin Husin.

Gejala Buli Secara Fizikal yang Semakin Berleluasa di Sekolah.

International Journal of Humanities, Management, and Social Science, vol. 2, no. 1, pp. 65-75, June 2019. DOI: 10.36079/lamintang.ij-humass-0201.24

Pengkaji mengatakan bahawa terdapat perbezaan persepsi antara pelajar dan guru berkenaan kekerapan buli di kalangan pelajar sekolah menengah. Perlakuan buli secara verbal merupakan perlakuan buli yang paling kerap berlaku berbanding perlakuan buli secara fizikal. Guru dan pelajar juga sependapat bahawa mereka perlu disedarkan dan saling bekerjasama untuk mencegah dan menangani masalah perlakuan buli ini di sekolah. Tahap keinginan pelajar untuk membuli berada pada tahap yang rendah. Vandalisma atau merosakkan harta benda sekolah merupakan isu keselamatan yang dianggap pelajar sebagai paling serius di sekolah. Rakan merupakan orang yang paling kerap dirujuk oleh pelajar berbanding pihak lain berkenaan masalah buli di sekolah. Program intervensi mempunyai hubungan yang signifikan dengan kekerapan perlakuan buli pada tahap sederhana. Menurut persepsi guru, program intervensi berasaskan sekolah terutama sekali peraturan sekolah dan lembaga disiplin sekolah merupakan program intervensi yang paling berkesan bagi mencegah dan menangani masalah perlakuan buli di sekolah menengah.

Teori yang berkaitan adalah Teori Pembelajaran Sosial Bandura. Menurut Bandura [7], tingkah laku buli yang merupakan salah satu cabang tingkah laku agresif merupakan satu tingkah laku yang dipelajari dan bukannya satu tingkah laku yang wujud secara semulajadi dalam diri individu. Menurut beliau lagi, antara ciri-ciri utama di mana sesuatu tingkah laku dipelajari oleh pelakunya adalah mengenai ciri-ciri persamaan yang terdapat di antara pelaku dengan orang yang ditiru. Mereka lebih cenderung dipengaruhi oleh seseorang yang penampilannya seperti mereka, daripada oleh seseorang yang menampilkan perbezaan yang ketara dengan mereka.

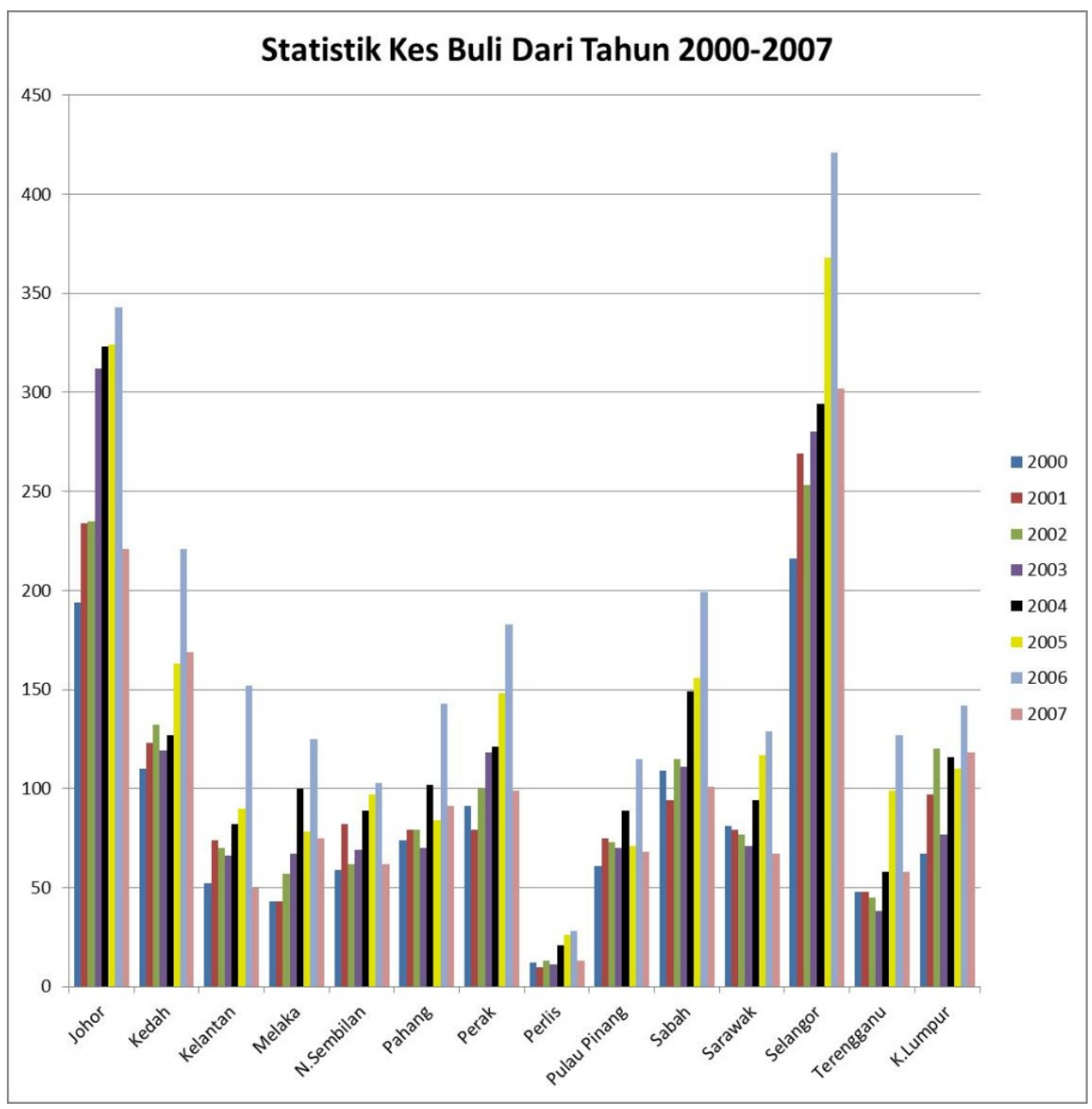

Rajah 1. Statistik Kes Buli dari Tahun 2000-2007 
Ngo Yew Yung, Nasharuddin Imraan Bin Rosli, Muhammad Afiq Aizaq Bin Mat Salleh@ Sukri, Nasharuddin Imraan Bin Rosli1, Fatin Nur Syahirah Binti Abdul Hamid, Nor Nasihah Binti Mohd Robi, Nurul Nasuha Binti Rosly, Mohd Razimi Bin Husin.

Gejala Buli Secara Fizikal yang Semakin Berleluasa di Sekolah.

International Journal of Humanities, Management, and Social Science, vol. 2, no. 1, pp. 65-75, June 2019. DOI: 10.36079/lamintang.ij-humass-0201.24

Dalam kajian Bandura [7] juga mendapati kadar peniruan tingkah laku berkurangan jika ciri-ciri persamaan antara remaja dan model kurang. Selain itu, usia dan jantina model juga memainkan peranan dalam peniruan tingkah laku. Beliau mendapati manusia lebih cenderung meniru model yang sama jantina dengannya. Umur juga mempengaruhi peniruan tingkah laku seseorang. Contohnya, remaja didapati mudah terpengaruh dengan tingkah laku rakan sebaya.

Seterusnya, aspek peneguhan dan ganjaran luaran memainkan peranan yang penting dalam aspek pembentukan tingkah laku buli, malah ia dapat dikatakan sebagai salah satu daripada sebab dan punca mengapa seseorang itu bertingkah laku agresif seperti membuli. Mengikut Teori Pembelajaran Sosial, tingkah laku agresif adalah tingkah laku instrumental yang dikawal oleh peneguhan dan ganjaran luaran [7]. Peneguhan dan ganjaran luaran ini mungkin dalam bentuk yang dapat dilihat seperti mempunyai ramai rakan ataupun perasaan seperti kepuasan dan kebanggaan. Statistik kes buli dari tahun 2000-2007 dibentangkan pada Rajah 1.

\section{Metodologi Kajian}

Reka bentuk kajian gejala buli secara fizikal yang semakin berleluasa di sekolah adalah berbentuk deskriptif dengan menggunakan keadah temu bual. Antara temu bual yang telah pengkaji buat adalah temu bual semi struktur. Format semi struktur terletak di antara temu bual berstruktur dan tidak berstruktur. Pengkaji menyoal soalan formal yang dibina tetapi penebual juga diberi kebebasan untuk menyoal lebih mendalam tentang jawapan responden yang telah ditanya secara formal. Tiga andaian temu bual semi struktur adalah setiap soalan boleh diberi dalam aras bahasa yang berbeza. Contohnya laras bahasa seorang doktor dan pelukis. Soalan boleh diubah suai dan disusun mengikut urutan tertentu supaya responden dapat memahami dengan baik dan pengkaji melihat isu kajian di bawah perspektif subjek, maka aras bahas boleh diubah suai mengikut keperluan.

Dalam kaedah temu bual, pengkaji telah menemu bual dengan empat guru master UPSI yang berpengalaman mengajar di sekolah. Dengan itu, pengkaji telah menyediakan beberapa soalan berkaitan dengan gejala buli fizikal yang berlaku di sekolah. Antara soalan tersebut dibentangkan pada Jadual 1.

Jadual 1. Soalan dan Jawapan Temu Bual

\begin{tabular}{|c|c|c|}
\hline BIL & SOALAN & JAWAPAN \\
\hline 1 & Siapakah selalu membuli dan dibuli? & $\begin{array}{l}\text { Responden 1: } \\
\text { Membuli biasanya pelajar senior membuli pelajar junior. } \\
\text { Responden 3: } \\
\text { Biasanya pelajar yang membuli memiliki fizikal yang besar dan pelajar } \\
\text { dibuli biasanya pelajar yang pendiam. }\end{array}$ \\
\hline 2 & $\begin{array}{l}\text { Adakah pelajar perempuan terlibat } \\
\text { dalam masalah buli? }\end{array}$ & $\begin{array}{l}\text { Responden 2: } \\
\text { Ada biasanya berebut teman lelaki. } \\
\text { Responden 4: } \\
\text { Pelajar perempuan kerap bergaduh diluar sekolah. }\end{array}$ \\
\hline 3 & Apakah tindakan pelajar yang dibuli? & $\begin{array}{l}\text { Responden 1: } \\
\text { Akan beritahu guru } \\
\text { Responden 2: } \\
\text { Di sekolah biasanya ada modul, dimana kaunselor akan panggil polis } \\
\text { untuk bagi "Talk \& Warness" berkaitan buli }\end{array}$ \\
\hline 4 & $\begin{array}{l}\text { Peringkat umur berapa yang membuli } \\
\text { dan dibuli? }\end{array}$ & $\begin{array}{l}\text { Responden 3: } \\
\text { Biasanya mana-mana boleh berlaku }\end{array}$ \\
\hline 5 & Dimanakah lokasi berlaku buli? & $\begin{array}{l}\text { Responden 1: } \\
\text { Tandas, asrama, atau mana-mana tempat yang tiada orang } \\
\text { Responden 4: } \\
\text { Dalam kelas juga boleh berlakunya buli tetapi diluar waktu sekolah }\end{array}$ \\
\hline 6 & $\begin{array}{l}\text { Apakah punca yang menyebabkan } \\
\text { buli berlaku? }\end{array}$ & $\begin{array}{l}\text { Responden 4: } \\
\text { Pembuli biasanya menunjukkan diri dia hebat supaya pelajar-pelajar } \\
\text { yang lain hormat kepada dia. }\end{array}$ \\
\hline 7 & $\begin{array}{l}\text { Pengalaman cikgu, macam mana } \\
\text { masalah buli yang terlibat campur } \\
\text { tangan pihak polis? }\end{array}$ & $\begin{array}{l}\text { Responden 1: } \\
\text { Pergi ke IPD@ IPK cari pengawal sekolah untuk mengetahui rekod } \\
\text { masalah sekolah.Refer kepada Inspektor atau sarjan dapat dokumen. }\end{array}$ \\
\hline
\end{tabular}


Ngo Yew Yung, Nasharuddin Imraan Bin Rosli, Muhammad Afiq Aizaq Bin Mat Salleh @, Sukri, Nasharuddin Imraan Bin Rosli1, Fatin Nur Syahirah Binti Abdul Hamid, Nor Nasihah Binti Mohd Robi, Nurul Nasuha Binti Rosly, Mohd Razimi Bin Husin.

Gejala Buli Secara Fizikal yang Semakin Berleluasa di Sekolah.

International Journal of Humanities, Management, and Social Science, vol. 2, no. 1, pp. 65-75, June 2019. DOI: 10.36079/lamintang.ij-humass-0201.24

\section{Dapatan Kajian}

\subsection{Strategi Menangani Masalah Buli di Sekolah}

Memandangkan masalah buli ini bukan lagi menjadi masalah yang ringan dan boleh dipandang enteng. Pihak sekolah dimana tempat pengkaji membuat kajian telah pun menjalankan beberapa inisiatif bagi menangani masalah buli ini dengan harapan supaya masalah buli ini dapat dikurangkan. Pihak sekolah tidak berhasrat untuk menjadikan sifar buli di sekolah kerana hal seumpama itu amatlah mustahil untuk dijalankan memandangkan jumlah pelajar yang besar. Sekiranya harapan pihak sekolah itu akan berjaya sekali pun semestinya mereka memerlukan kerja keras dan kerjasama yang kuat dari semua pihak masyarakat, ibu bapa, murid serta guru. Jika difikir sejenak amatlah mustahil untuk mana-mana sekolah untuk menjadikan sifar buli di sekolah. Hal ini kerana murid-murid yang hadir dari latar belakang yang berbeza yang membuatkan mereka menunjukkan tingkah laku yang pelik.

Menurut temubual yang telah pengkaji jalankan bersama empat orang responden. Responden telah menceritakan banyak program yang telah pun pihak sekolah laksanakan bagi membendung masalah buli ini dari berleluasa. Antara program yang telah pihak sekolah lakukan ialah homeroom, program jati diri, program bertemu kaunselor dan banyak lagi. Menurut responden, program homeroom ini sedikit sebanyak membantu murid yang bermasalah. Hal ini kerana mereka sering dipantau oleh guru. Homeroom atau dikenali sebagai program mento-mentee yang mana seorang guru akan mengambil 15 orang pelajar dibawahnya untuk dikawal dan dibimbing supaya lebih terkawal dan mengurangkan jumlah pelajar yang besar. Sekiranya jumlah pelajar yang mempunyai beribu-ribu orang ini tidak dikecilkan dan ingin membendung dengan jumlah yang ramai sedikit sebanyak akan menyukarkan objektif sesuatu program. Dengan adanya program homeroom ini guru akan lebih senang untuk mendekati murid dengan bertanya kepada murid akan masalah yang mereka hadapi sehingga membolehkan mereka melakukan kegiatan buli. Murid-murid juga akan lebih selesa untuk bercerita kepada guru secara bersemuka dan tidak melibatkan orang ramai. Hal ini kerana ada sesetengah murid mereka berasa segan atau malu untuk bekongsi cerita atau pun masalah jika ramai mata yang memandang. Setelah homeroom ini dilaksanakan 4 respoden ini, didapati pembuli dapat mengurangkan kegiatan mereka kerana mungkin masalah mereka semakin hilang.

Selain itu, pihak kaunseling ada membuat program seperti program jati diri bagi pelajar yang sering melakukan kegiatan buli. Program ini khusus bagi mereka yang pernah melakukan buli ataupun cuba untuk terjebak dengan masalah buli. Dalam menjayakan program ini murid-murid perlulah memberi kerjasama dengan baik kepada pihak kaunseling supaya objektif mereka tercapai. Pada kebiasaannya, pihak sekolah akan memanggil pakar motivasi dari luar untuk datang ke sekolah memberi taklimat ataupun memberi nasihat untuk pembuli supaya mereka lebih sedar dan berniat untuk meninggalkan kegiatan buli yang mana akan memberi kesan kepada pelajar lain. Dalam program ini juga guru kaunseling terlibat untuk mendengar suara hati pelajar yang membuli. Hal ini kerana, pelajar itu sendiri bukannya berniat untuk membuli akan tetapi mereka tertekan dengan cara hidup mereka atau pun ada yang mempunyai masalah keluarga. Masalah seumpama inilah yang akan menyebabkan mereka cenderung melakukan kegiatan buli di sekolah. Jika mereka melakukan kegiatan buli meraka akan berasa puas hati dan tidak tertekan dengan masalah. Malah ada juga yang membuli ini kerana mempunyai masalah dengan keluarga ada yang ibu bapa bercerai, ada yang ayahnya kaki pukul, ada yang ibu bapa terlalu sibuk dengan kerjaya sehingga mengabaikan anakanak. Ibu bapa itu sendiri tidak mengambil tahu perasaan anak-anak menyebabkan anak kurang kasih sayang dari ibu bapa. Hal ini kerana, jika anak mempunyai masalah mengenai pelajaran anak-anak tiada tempat untuk mengadu atau pun meluahkan rasa hati mereka kepada ibu bapa oleh kerana ibu bapa terlalu sibuk mengejar kerjaya berbanding anak. Hal seumpama inilah yang menyebabkan pelajar ke sekolah dan melakukan kegiatan buli bagi menghilangkan masalah yang membebani fikiran mereka. Mereka akan berasa puas jika melakukan kegiatan buli.

Seterusnya, pihak sekolah juga memberi peluang kepada pelajar yang mempunyai masalah datang berjumpa dengan kaunselor di bilik kaunseling sekiranya mereka malu untuk menyertai sebarang program yang dianjurkan oleh pihak sekolah. Pertemuan empat mata seumpama ini lebih berkesan kerana pelajar akan bercerita tanpa rasa segan dan yakin untuk memberitahu rahsia mereka kepada kaunselor. Dalam pertemuan seperti ini, kaunselor akan menasihati pelajar dengan cara mendidik dan mungkin akan memberi kesan kepada pelajar. Kebanyakkan pelajar yang membuli ini kerana berasa mereka sudah berada di sekolah itu lama dan mempunyai masalah keluarga. Maklumat ini diambil dari kaunselor yang pernah menangani kes buli dan responden sendiri pernah menerima kes buli yang 
Ngo Yew Yung, Nasharuddin Imraan Bin Rosli, Muhammad Afiq Aizaq Bin Mat Salleh @, Sukri, Nasharuddin Imraan Bin Rosli1, Fatin Nur Syahirah Binti Abdul Hamid, Nor Nasihah Binti Mohd Robi, Nurul Nasuha Binti Rosly, Mohd Razimi Bin Husin.

Gejala Buli Secara Fizikal yang Semakin Berleluasa di Sekolah.

International Journal of Humanities, Management, and Social Science, vol. 2, no. 1, pp. 65-75, June 2019. DOI: 10.36079/lamintang.ij-humass-0201.24

berlaku di asrama tempat pelajar tinggal. Pada awalnnya, pembuli ini bukannya bersifat agresif semenjak dari awal mereka masuk ke sekolah, tetapi setelah mereka memasuki menengah atas dan mereka berasa sudah lama berada di sekolah serta yakin pelajar baru akan takut dengan mereka barulah mereka mula membuli. Disebabkan itu, kebanyakkan pembuli hanya dari menengah atas iaitu tingkatan 4 dan 5 . Hal ini kerana mereka rasa mereka sudah besar dan boleh melakukan apa saja sesuka hati mereka. Pelajar dari menengah rendah jarang terlibat dengan masalah buli seperti menjadi pembuli kebanyakkan dari mereka akan menjadi mangsa buli dari pelajar senior iaitu menengah atas.

Pihak kaunseling juga meminta supaya pelajar yang dibuli datang meminta nasihat dari pihak kaunselor supaya mereka tidak berasa tertekan dan rendah diri apabila dibuli. Kebanyakkan mangsa buli akan takut untuk berjumpa guru kaunseling kerana mereka bimbang diketahui oleh pembuli dan mangsa akan dibuli dengan lebih teruk lagi. Jika mangsa takut untuk bersuara pembuli akan berasa selesa kerana tindakan tidak akan diambil keatas mereka. Kebanyakkan mangsa buli akan murung sehingga akan menyebabkan tekanan kepada emosi mereka serta akan menjejaskan pelajaran. Oleh itu, pihak sekolah meminta kepada mangsa untuk berjumpa dengan pihak kauseling supaya memulihkan balik semangat mereka dan berasa yakin untuk berhadapan dengan pembuli. Menurut kaunselor lain pula, tidak ramai mangsa yang datang berjumpa dengan beliau untuk menceritakan perkara sebenar kerana takut kepada pembuli. Responden mengetahui akan hal itu melalui kawan mangsa. Sebenarnya, jika mangsa sering berjumpa kaunselor untuk menceritakan masalah mereka potensi mereka untuk dibuli itu akan berkurang kerana pembuli akan takut untuk meneruskan kegiatan mereka. Hal ini kerana mangsa terlalu rapat dengan guru. Oleh itu, mangsa perlu berjumpa pihak kaunseling bagi memudahkan pihak mereka mengesan siapa yang sering melakukan kegiatan buli sekali gus dapat membendung masalah ini semakin berleluasa di sekolah.

\subsection{Isu Berkaitan Menangani Kejadian Buli di Sekolah}

Hasil daripada temu bual pengkaji berasama 4 orang responden, masalah yang pihak sekolah hadapi untuk menangani masalah buli ini seperti jumlah pelajar yang besar sedikit sebanyak menyukarkan pihak sekolah. Dalam temu bual itu juga mereka memberitahu pihak sekolah tidak mengharap agar kegiatan buli ini menjadi sifar oleh sebab jumlah pelajar yang ramai. Guru-guru di sekolah tersebut berbincang dan berusaha untuk menjadikan sekolah mereka sebagai salah sebuah sekolah yang sifar buli tetapi jika difikirkan balik amatlah mustahil bagi guru yang berjumlah kecil untuk mengawal pelajar yang ramai. Jika difikir secara logik sekali pun amatlah mustahil. Jumlah pelajar yang ramai ini juga menjadikan penyebab semakin mudah kegiatan buli ini berlaku kerana pelajar tahu bahawa guru tidak mampu mengawal mereka setiap orang maka mereka bebas melakukan kegiatan tersebut. Tambahan pula, kesemua pelajar ini tinggal di asrama dan hanya beberapa orang sahaja warden yang ditugaskan untuk mengawal mereka. Kesulitan seumpama inilah yang menyebabkan kegiatan buli semakin berleluasa di sekolah.

Selain itu, tingkah laku ibu bapa juga menjadi kekangan bagi pihak sekolah dalam menangani masalah buli ini. Kebanyakkan ibu bapa tidak percaya anak mereka mempunyai masalah di sekolah, jika mendapat makluman daripada pihak sekolah mereka melenting dan menyalahkan pihak sekolah. Pada hakikatnya, mereka sendiri tidak mengenali peribadi anak mereka dengan lebih mendalam. Hal ini kerana, anak-anak mereka membesar di asrama dan menghabiskan masa mereka bersama guru di sekolah. Ibu bapa hanya berjumpa dengan anak-anak pada hujung minggu dan musim cuti sekolah. Pertemuan bersama anak mereka tidak lama seperti mana guru dan warden menjaga anak mereka di sekolah. Sekiranaya pihak sekolah mengenakan tindakan terhadap anak mereka, mereka akan datang ke sekolah dengan perasaan marah dan menyalahkan pihak sekolah dengan menyatakan pihak sekolah mengenakan tindakan yang tidak sepatutnya. Walhal, pihak sekolah telah pun membuat beberapa tapisan sebelum menghantar apa-apa notis kepada ibu bapa supaya apa yang disampaikan kepada ibu bapa adalah info yang tepat. Walaupun, pihak sekolah meneliti setiap tindakan mereka ada sahaja yang dikomen oleh ibu bapa untuk menunding jari kepada pihak sekolah. Sebagai contoh, surat gantung sekolah selama dua minggu akan dikeluarkan sekiranya pelajar melakukan kesalahan buli sebanyak 2 kali dan telah pun diberi nasihat daripada kaunselor. Pihak sekolah tidak akan sesuka hati membuat tindakan tanpa usul periksa.

Seterusnya, pihak sekolah juga menghadapi kekangan dalam mengatasi masalah buli apabila mangsa buli tidak ingin memberi kerjasama kepada pihak sekolah. Kebanyakkan mangsa buli tidak melaporkan kepada guru disiplin atau warden bahawa mereka telah dibuli. Hal ini kerana mangsa berasa takut dan gerun dengan tindakan pembuli. Mereka takut sekiranya mereka membuat aduan 
Ngo Yew Yung, Nasharuddin Imraan Bin Rosli, Muhammad Afiq Aizaq Bin Mat Salleh @, Sukri, Nasharuddin Imraan Bin Rosli1, Fatin Nur Syahirah Binti Abdul Hamid, Nor Nasihah Binti Mohd Robi, Nurul Nasuha Binti Rosly, Mohd Razimi Bin Husin.

Gejala Buli Secara Fizikal yang Semakin Berleluasa di Sekolah.

International Journal of Humanities, Management, and Social Science, vol. 2, no. 1, pp. 65-75, June 2019. DOI: 10.36079/lamintang.ij-humass-0201.24

mereka akan dibuli dengan lebih teruk lagi. Semasa mangsa dibuli mangsa telah pun diugut oleh pembuli supaya jangan sesekali melaporkan kepada sesiapa mengenai kegiatan jahat mereka. Disebabkan itu mangsa berasa takut untuk melaporkan. Hal ini secara tidak langsung akan membuka ruang kepada pembuli menjalankan kegiatan jahat mereka secara berlarutan kerana tiada seorang pun yang sanggup membuat aduan kepada pihak sekolah. Walaupun begitu, bukan semua mangsa yang takut dengan pembuli ada juga yang berani untuk pertahankan diri mereka dengan cara melaporkan kepada guru dispilin ada juga yang berjumpa kaunselor bagi mendapat nasihat. Jika kesemua mangsa takut untuk bersuara keadaan akan menjadi makin sukar untuk dibendung. Pihak sekolah sukar untuk mencari dan mengenal pasti identiti si pembuli sehingga menjadi penyebab masalah ini semakin berlelusa. Oleh itu, semua yang terlibat haruslah memberi kerjasama kepada pihak sekolah dalam membendung kegiatan buli ini semakin berleluasa memandangkan untuk menjadikan masalah buli ini sifar adalah mustahil.

\section{Perbincangan}

\subsection{Analisis SWOT}

Berdasarkan kajian pengkaji mengenai isu bulifizikal di sekolah, pengkaji mendapati bahawa kes buli ini sentiasa berlaku di setiap sekolah sama ada di sekolah rendah mahu pun menengah. Untuk membincangkan lebih mendalam lagi mengenai buli ini pengkaji menggunakan analisis SWOT untuk menerangkan lagi hasil kajian pengkaji.

SWOT adalah salah satu teknik analisis organisasi untuk mengetahui bagaimana keadaan organisasi yang berkaitan pada masa sekarang serta bagaimana dengan keadaaan yang akan dihadapi pada masa hadapan dengan mempertimbangkan fakktor-faktor kekuatan, kelemahan, halangan dan ruang untuk penambahbaikan. Selain itu, SWOT juga digunakan untuk mempertimbangkan sesuatu kerja yang kita hasilkan. Dapatan kajian Beale [8], menyatakan bahawa perlakuan buli memberi kesan buruk terhadap mangsa buli di mana mereka akan menderita dari aspek sosial dan akademik. Ini akan mengakibatkan mereka untuk memilih untuk bunuh diri dan ianya merupakan akibat yang paling kronik.

\subsection{Kekuatan}

Sehubungan dengan itu, berdasarkan analisis SWOT, kekuatan untuk menangani isu buli di sekolah dengan melalui mata pelajaran tertentu seperti Pendidikan Moral, Pendidikan Islam, Pendidikan Sivik dan sebagainya. Menurut responden, melalui pendidikan ini, para pelajar mendapat kesedaran dan mempelajari kebaikan serta menjauhi gejala kurang baik. Selain itu, kekuatan yang ada untuk membendung kes buli di sekolah adalah dengan mengadakan kempen dan ceramah kesedaran tentang gejala membuli di setiap sekolah. Melalui cara ini, remaja dapat mengetahui kesan yang diperolehi daripada melakukan gejala membuli dan berupaya untuk tidak melakukan perbuatan ini terhadap orang lain. Contohnya, pihak sekolah akan meminta bantuan daripada pihak polis untuk memberi ceramah tentang "awareness of buli". Seterusnya, peranan ibu bapa dan pihak sekolah juga amat penting bagi mengurangkan gejala buli di sekolah. Hal ini kerana, jika berlaku pergaduhan, ibu bapa kepada mangsa buli akan melaporkan kepada pihak sekolah. Pihak sekolah akan mengambil tindakan terhadap si pembuli dengan mengenakan hukuman yang setimpal kepada pelajar tersebut agar dia tidak mengulangi perbuatan itu lagi dan juga dijadikan sebagai iktibar kepada pelajar yang lain. Disiplin dan peraturan sekolah juga diperketatkan dan ditekankan kepada para pelajar supaya para pelajar mengikuti etika peraturan sekolah dan tidak membuat kesalahan seperti penglibatan dalam gejala sosial seperti membuli.

\subsection{Kelemahan}

Kelemahan yang dapat mempengaruhi kes buli di sekolah ialah bilangan pelajar yang terlalu ramai telah menyukarkan guru untuk mengawal kes buli yang terjadi di sekolah. Hal ini demikian kerana, sebilangan mangsa buli enggan dan mendiamkan diri dari melaporkan mangsa telah dibuli oleh pelajar lain. Kajian responden juga menyatakan bahawa mangsa buli akan mengalami trauma sehingga menyebabkan dia takut berkawan dengan pelajar lain dan hilang fokus untuk belajar. Pengawasan yang longgar dan kelemahan peraturan di sekolah akan memberi peluang kepada pelajar yang ingin menjalankan aktiviti pembulian mereka terhadap pelajar lain. Di samping itu, sistem sekolah yang terlalu mementingkan pencapaian akademik dan mengetepikan aspek sukan kokurikulum, pembinaan sahsiah dan kerja berpasukan. Pelajar juga terdedah dengan media sosial 
Ngo Yew Yung, Nasharuddin Imraan Bin Rosli, Muhammad Afiq Aizaq Bin Mat Salleh @, Sukri, Nasharuddin Imraan Bin Rosli1, Fatin Nur Syahirah Binti Abdul Hamid, Nor Nasihah Binti Mohd Robi, Nurul Nasuha Binti Rosly, Mohd Razimi Bin Husin.

Gejala Buli Secara Fizikal yang Semakin Berleluasa di Sekolah.

International Journal of Humanities, Management, and Social Science, vol. 2, no. 1, pp. 65-75, June 2019. DOI: 10.36079/lamintang.ij-humass-0201.24

yang memaparkan aksi dan tingkah laku yang kurang baik sehingga menyebabkan pelajar mudah terikut. Responden juga mengatakan bahawa kes buli ini menjadi ikutan dari tahun ke tahun yang lain. Contohnya, pelajar senior membuli pelajar junior dan apabila pelajar junior meningkat dewasa, perlakuan tersebut akan dibalas balik.

\subsection{Halangan}

Responden menyatakan bahawa halangan untuk membendung kes buli ialah sekolah mengalami kurang peruntukan untuk membeli dan memasang kamera litar tertutup (CCTV) di setiap bangunan sekolah. Hal ini kerana, untuk memasang CCTV melibatkan kos yang tinggi selain menjadi isu kerana tiada privasi. Sebegai contoh,di tandas adalah tempat yang paling popular untuk pelajar membuli kerana tiada CCTV yang akan dipasang di sana disebabakan oleh hak privasi. Seterusnya, halangan yang lain untuk menangani gejala buli ini adalah tiada kerjasama antara pelajar dengan guru. Selain itu, ditambah lagi pada zaman kini seseorang guru atau pelajar tidak boleh menyentuh pelajar lain kerana hal ini boleh dikategorikan sebagai penderaan. Justeru, perkara ini merupakan salah satu cabaran yang dihadapi oleh guru untuk memberi hukuman yang setimpal kepada mereka yang bermasalah seperti hukuman keatas pembuli.

\subsection{Ruang untuk Penambahbaikan}

Ruang untuk penambahbaikan bagi menangani kes buli ialah melakukan program kaunseling secara berkala. Hal ini akan menjadikan pelajar lebih mengetahui kesan dan tindakan yang akan dilakukan sekiranya pelajar dibuli oleh pelajar lain. Selain itu, pihak pentadbiran sekolah juga tidak wajar utuk menyembunyikan kes buli di kalangan pelajar daripada pengetahuan pihak Jabatan Pelajaran agar dapat diambil tindakan. Pihak sekolah perlu mempunyai peraturan yang jelas berkaitan dengan buli. Ini bukan sahaja dilakukan dengan menampal poster antibuli di sekolah, tetapi juga mengedarkan risalah anti buli kepada setiap pelajar untuk dibaca bersama dengan ibu bapa. Maklumat yang terkandung dalam risalah ini merangkumi konsep buli, petua mudah untuk menangani insiden buli. Seterusnya, di dalam kelas juga perlu diwujudkan satu peraturan kelas berkaitan dengan toleransi sifar tentang buli. Peraturan tersebut mestilah menyenaraikan semua tingkah laku yang disifatkan sebagai tingkah laku buli fizikal, dan hukuman yang akan diterima jika ditangkap atau dilapor melakukannya. Seseorang guru hendaklah mengambil berat atas segala aduan pelajar mengenai apa-apa yang berlaku di sekolah. Walau bagaimanapun, dalam konteks ini, guru tersebut haruslah tidak mengambil tindakan terburu-buru dengan terus "menyerang" pelajar yang dikatakan membuli pelajar lain itu. Guru perlu menyiasat terlebih dahulu selepas mendapat aduan. Tunjukkan kepada pelajar bahawa mereka tidak keseorangan menghadapi masalahnya dan guru akan sentiasa berada disisi untuk bercerita dan mendengar sebarang masalah daripada mangsa buli. Sekolah juga haruslah menggalakkan pelajar supaya melibatkan diri dalam kelab pencegah jenayah. Hal ini demikian kerana, pelajar akan memperolehi lebih banyak pengetahuan tentang cara-cara menangani kes buli sekiranya pelajar menjadi pemangsa kes itu. Oleh itu, pelajar tidak akan melakukan kes buli ini kerana hukuman yang akan dikenakan amat berat sehingga boleh meyebabkan pelajar tersebut dibuang sekolah. Seterusya, pihak sekolah perlu memastikan pelajar pulang tepat pada waktu persekolahan tamat dengan mengarahkan pengawal keselamatan kerap melakukan rondaan di sekitar sekolah bagi memastikan pelajar tiada lagi di sekolah. Hal ini penting untuk mencegah daripada berlakunya masalah-masalah serius seperti kes buli ini atau sebagainya.

Teori yang boleh dikaitkan dengan analisis SWOT ialah teori perkembangan kognitif Jean Piaget. Menurut Piaget [9], proses pemikiran kita berubah secara menyeluruh bermula selepas lahir sehingga kita mencapai kematanga. Oleh itu, setiap individu akan mencuba untuk memahami dan mengadaptasi perubahan-perubahan yang berlaku di persekitaran mereka.

Menurut Piaget, setiap individu cenderung untuk memahami persekitaran mereka. Adaptasi adalah proses perubahan skema lama kepada skema baru di mana melibatkan dua proses yang saling berkait iaitu asimilasi dan akomodasi. Sebagai contoh, guru kaunseling di sekolah mengadakan aktiviti yang bersesuaian seperti ceramah dan program untuk memberi kesedaran kepada pelajar bagi membuang gejala buli di sekolah contohnys kempen anti buli, kempen sifar buli. Justeru itu, dengan adanya kempen tersebut, ianya serba sedikit dapat mengurangkan kadar buli secara fizikal di sekolah di Malaysia. Pihak sekolah juga perlu sentiasa memastikan bahawa pengawasan di setiap sekolah seperti di belakang bangunan sekolah dan kaki lima yang sunyi diperketat supaya tidak memberi sebarang peluang kepada pelajar yang mempunyai keinginan untuk membuli mangsanya. Walau manapun, 
Ngo Yew Yung, Nasharuddin Imraan Bin Rosli, Muhammad Afiq Aizaq Bin Mat Salleh @ Sukri, Nasharuddin Imraan Bin Rosli1, Fatin Nur Syahirah Binti Abdul Hamid, Nor Nasihah Binti Mohd Robi, Nurul Nasuha Binti Rosly, Mohd Razimi Bin Husin.

Gejala Buli Secara Fizikal yang Semakin Berleluasa di Sekolah.

International Journal of Humanities, Management, and Social Science, vol. 2, no. 1, pp. 65-75, June 2019. DOI: 10.36079/lamintang.ij-humass-0201.24

pihak kaunselor sekolah perlu bekerjasama dengan ibu bapa serta kanak-kanak bermasalah supaya bimbingan serta kaunseling boleh diberikan [10].

\section{Kesimpulan}

Secara keseluruhan, melalui dapatan kajian yang dibentangkan maka dapatlah dirumuskan mengenai perlakuan buli. Dalam kalangan murid di sekolah begitu serius, terutamanya di sekolah menengah. Perlakuan buli di sekolah menengah sesuatu yang perlu diambil perhatian serius seperti mana di sekolah-sekolah dalam bandar dan luar bandar yang lain. Kita sesungguhnya tidak boleh melihat keskes buli yang berlaku di sekolah sebagai satu masalah terpinggir.

Walaupun nisbah kejadian adalah sangat kecil tetapi masalah ini boleh menjadi satu barah dalam usaha membentuk masyarakat madani. Malah perlu dilihat semula sejauh manakah keseimbangan antara tumpuan kepada akademik dan hal-hal sosial.

Usaha untuk menangani masalah buli di sekolah bukanlah hanya merupakan tanggungjawab pada satu-satunya pihak samada ibu bapa, penjaga atau guru tetapi semua pihak yang terlibat. Oleh itu, kesedaran diri amat penting dan merupakan salah satu cara penyelesaian yang terbaik antara cara-cara penyelesaian yang lain. Kementerian Pelajaran Malaysia, Jabatan Pelajaran Negeri termasuk agensiagensi kerajaan juga perlu memainkan peranan dalam membantras perlakuan buli di sekolah.

Secara keseluruhannya, disiplin merupakan elemen yang paling asas dan penting dalam diri seseorang individu walaupun pembentukan keperibadian ini boleh berlaku dengan sendiri. Pihak sekolah seharusnya lebih memberi perhatian ke atas pembentukan sahsiah pelajar daripada mengenakan hukuman keras ke atas diri pelajar yang terlibat dalam masalah disiplin. Hal ini jika tidak diambil berat ia mungkin akan menyebabkan masalah disiplin menjadi semakin rumit dan serius.

Selain itu, pengkaji telah berjaya mencapai objektif dan matlamat pengkaji dalam kajian ini. Pengkaji berjaya mendapatkan respon guru-guru melalui kaedah temu bual yang pengkaji jalankan, tentang cara dan teknik berkesan yang guru gunakan terhadap pelajar-pelajar bagi mengelakkan kejadian buli, pengalaman mengendali kes buli, sejarah kes buli serta cadangan penambahbaikan pada masa akan datang.

\section{Rujukan}

[1] N. F. Yaakub, Hentikan Buli di Sekolah Anda: Panduan Sekolah Menengah. Petaling Jaya: Sutrapadu, 2006.

[2] A. H. Yahaya, Y. Boon, S. Hashim, M. S. Mustaffa, and Z. B. Muhamad, Indeks Perlakuan Buli di Kalangan Pelajar-Pelajar di Sekolah Menengah dan Rendah di Malaysia. Johor: UTM, 2008.

[3] K. Mahadi, Tingkah Laku Buli dalam Kalangan Pelajar Sekolah Menengah Kebangsaan Agama di Sarawak. Batu Lintang: Institut Penguruan Batu Lintang, 2007.

[4] S. Freud, Interpretation of Dream, $3^{\text {rd }}$ Edition. New York: Brill A. A. Macmillan, 1913.

[5] J. Hassan, R. Rashid, S. F. Surfahani, and M. K. N. A. Aziz, "Buli di Kalangan Sekolah Rendah Luar Bandar: Kajian Kes di Kawasan Felda Utara Kedah- Perlis, Malaysia," Jurnal Psikologi Malaysia, vol. 30, no. 1, pp. 113-125, 2016.

[6] A. Maslow, Toward a Psychology of Being. New York, NY: Van Nostrand Reinhold, 1968.

[7] A. Bandura, "Health Promotion from the Perspective of Social Cognitive Theory," Psychology and Health, vol. 13, no. 4, pp. 623-649, 1998.

[8] A. V. Beale, "Bullybusters: Using Drama to Empower Students to Take a Stand against Bullying Behavior," Professional School Counseling, vol. 4, pp. 300-306, 2001.

[9] J. Piaget, the Psychology of Intelligence. London: Rout Idge and Kegan Paul, 1950.

[10] A. T. A. Termizi, "Buli: Tanggungjawab Semua," Utusan Online, vol. 494455. [Online]. Available: http://www.utusan.com.my/rencana/utama/buli-tangungjawab-semua-1. [Accessed: June. 18, 2017]. 